\title{
A New Approach to Teaching English Poetry to EFL Students
}

\author{
Mohammad Khatib \\ Allameh Tabataba'i University, Iran \\ Email: mkhatib27@yahoo.com
}

\begin{abstract}
Poetry like other literary genres exists to be enjoyed and appreciated. The difficult task facing any instructor is to develop this sense of appreciation and enjoyment in students who are not interested in poetry. For a long time, literature in general and poetry in particular, was purged from the teaching programmes on the ground that it made no contribution to learning a foreign language for practical purposes. Fortunately, in the past few decades there has been a renewed interest in using literature in the language classroom. Despite the renewed interest in teaching literary texts in the classroom, little has been written about teaching poetry to college-level students in Iran. Many English instructors along with many university students do not enjoy English poetry. Even a majority of them express a negative attitude towards poetry. No one can deny that poetry is difficult not only for EFL students, but also for native speakers. My long experience in teaching poetry to Iranian college students has forced me to come to the conclusion that the students' negative attitude towards poetry can be ascribed, among many other facts, to (a) inappropriate selection of the texts and (b) ineffective teaching methodology. This study suggests a new approach to teaching English poetry in EFL situations. The purpose of this study was to determine the relative effectiveness of this approach in improving the students' attitude towards English poetry at college level at Allameh-Tabataba'i University in Tehran-Iran.
\end{abstract}

Index Terms - traditional approach, language-based approach, attitude

\section{INTRODUCTION}

English poetry has been taught in many non-native countries as well as in Iran for many years, but what has dominated the teaching of poetry is the traditional approaches. Teachers lecture about the things that will prepare the students for a particular exam and will not encourage them to share their own views with their peers and teachers.

The main objective of teaching literature in the undergraduate departments of Iranian universities is to acquaint students with various literary genres, and consequently introducing them to the social, cultural, literary and intellectual backgrounds of other nations. Although instructors vary slightly in their treatment of literature, a common tendency can be traced out in their approaches. Adopting a traditional approach to teaching poetry, many instructors devote most of the valuable time of the class to "extrinsic" properties of literary texts imparting biographical, historical, aesthetic and philosophical information to the students. A large number of students will manage to pass the final exams by memorising the critical reviews of the poems. How many students brought up by this method will be the voluntary readers of poetry after they graduate from the college? Undoubtedly many of them will regard their literature classes as boring, monotonous and uninteresting.

Although the attitude of many instructors towards teaching poetry has changed considerably in the past years and even some ESP teachers believe that a well-chosen approach to the teaching of literature has some benefits for their students, there are very few teachers who advocate the inclusion of a new methodology to teaching poetry in their syllabus. Some instructors are ready to teach novels, short stories, plays and even essays, but very reluctant to teach poetry because they are well aware that with the old methods they cannot make poetry come alive for their students.

Thus, if the methodology currently used in the poetry classes is not effective and successful, it is worthwhile experimenting with other methods and finding out whether they will yield significantly different result both on educational and the attitudinal levels.

\section{REVIEW OF LITERATURE}

The teaching of poetry to EFL students has always been a very demanding task. It is commonly assumed that English poetry is too difficult for foreign students to cope with and therefore it will be out of their reach. For almost two or three decades, literature, in general, and poetry in particular, which had played an essential role in foreign language teaching in many countries has been excluded from language classrooms. The significant role of literature faded gradually as linguistics became the focal point of language programmes. The upheaval created by American structural linguists played a crucial role in this change of attitude. Linguists such as Topping (1968, quoted from Spack, 1985) argue that "literature should be excluded from the ESL curriculum because of its structural complexity, lack of conformity to standard grammatical rules and remote cultural perspectives" (p. 704). 
Widdowson (1975) and Povey (1967) among many others discuss the unfortunate consequences of separating English language from English literature in EFL/ESL schools. Luckily, in recent years, there has been an increasing interest among scholars, in both Iran and other countries, in reviving literature as a means of acquiring language proficiency. Scholars, searching for new resources to decrease the monotony of the classes, have stressed the benefits of using literary texts as the basis for imaginative, interactive activities. Widdowson $(1975 ; 1984)$ raised the fundamental issues and these have been examined, developed, modified and amplified by Brumfit and Carter (1986), Duff and Maley (1989), Lazar (1993), Parkinson and Reid Thomas (2000) and many other scholars of note.

If we review a number of surveys dealing with the situation of English literature in EFL/ESL situations, we can see striking similarities in the negative attitudes that students express towards learning poetry. Hirvela and Boyle (1988) report that only $6 \%$ of the Hong Kong Chinese students who were involved in the survey favoured poetry more than other literary genres and $73 \%$ of them found poetry the most difficult and intimidating literary form.

Povey (1979), a vehement advocate of teaching poetry in EFL situations, believe that instructors of poetry are somehow responsible for causing the negative attitude of students towards verse:

Ironically, often one of the most difficult things about teaching poetry to foreign students in handling the teacher's own deeply wrought unhappiness with verse, the result of experiences he or she has suffered (p. 164).

Arthur (1968) ascribes the aversion of students toward literature to ignoring the students' response and their private exchange with the literary text. "If literature is to become a successful part of an ESL programme, ways must be found to make literature both useful and enjoyable" (p. 200).

My long experience in teaching poetry to Iranian college students has impelled me to come to the conclusion that the major reasons of students' failure in understanding and appreciating English poetry are (a) inappropriate selection of texts and (b) ineffective teaching methodology.

The advocates of the traditional approaches to teaching literature consider students as empty containers to be filled by the knowledge imported by an omniscient teacher. The practitioners of these approaches normally bombard students with biographical information about the author, political, religious and philosophical ideas related to the text and explaining rhetorical devices and figures of speech such as metre, rhyme, metaphor, alliteration, assonance and the like. But the proponents of the language-based approach believe that studying the language of literary text will help to integrate the language and literary syllabus more closely. Students can develop a response to literature through examining the linguistic evidence in the text. Rather than being passive recipients, the techniques used in this approach urge them to be active participants expressing their own conclusions and interpretations of a literary text.

The primary aim of the "new approach" proposed in this study is to stimulate students to read and to encourage their responses. The main focus of attention in this approach is the text itself, not commentary or background information about the text. This approach emphasises vocabulary expansion, reconstruction, reduction, replacement, matching, reading loud by instructor, silent and oral reading by students, writing poetry and many other techniques. To this end the following research questions were formulated:

1. Will the students improve their attitude towards English poetry after being taught with the new approach?

2. Will the new approach to teaching poetry yield significantly better results in motivating the students to read more poems than the traditional approach?

\section{METHOD}

\section{A. Participants}

The subjects of this study were 200 students (106 females and 94 males) majoring in English Translation and English Literature at College of Persian Literature and Foreign Languages of Allameh Tabataba'i University. There were 6 groups altogether, three groups were randomly chosen as the control and three as the experimental groups. The number of students was approximately the same for all groups. All the participants were in their third semester of college education, having passed the average of 40 credits in their previous semesters. All the students had Persian as their native language and knew no other foreign language except English. They had taken no poetry courses in English prior to the experiment.

\section{B. Materials}

Sixty-five poems were used in this study. Forty-two of them served as teaching materials during the time this study was being carried out. Twenty-three poems were given to the students to be read on their own. Various themes such as childhood, love, old age, loneliness, fidelity, nature, etc. were explored in the selection. Some of the poems had the same or related themes, offering students the possibility of comparing and contrasting the ideas expressed in them as well as concentrating on their language. Utmost care had been taken to select poems to be enjoyable and interesting and not to offer any cultural gap to make them difficult to understand.

\section{Procedures}

a. The Control Groups.

Since in the traditional approach to teaching poetry the "extrinsic" factors are normally emphasised rather than the "intrinsic" elements, to teach the control group the following steps were used: 
1. The instructor distributed the poems to be covered at the beginning of each session.

2. He read the poem aloud once with the voice colouring.

3. The students were asked to read the poem a few times and then were asked to express the poet's intentions.

4. A short biography of the poet was given to the students.

5. The historical, political, and/or social background against which the poems had been written was discussed.

6. The figures of speech and other literary devices were explained.

7. The instructor would paraphrase the difficult lines and would talk about the central idea expressed in the poem.

8. One or two students were invited to read the poem aloud to the class.

9. The students were given some poems to read on their own with no activities attached.

b. The Experimental Groups.

1. The seating arrangement was changed from traditional style of rows to a complete circle. This seating arrangement prepared the scene for small-group learning.

2. The activities varied greatly in length. Some took two or three minutes and some took half an hour to finish.

3. The activities in the experimental groups followed the same general design for all the sessions. There were four main parts:

a) Pre-reading activities

b) While-reading activities

c) Follow up

d) Reading alone

4. The activities of the Pre-Reading section were designed to awaken initial interest in the poem, to familiarise students with the possible contents of the poem they were to read.

5. In the While Reading section each poem was followed by activities aimed at helping the students to be involved with the text as much as possible. Some of the most important activities used in this section are the following:

a) Replacement Activities: students removed certain elements and replaced them with others. They changed active verbs into passive forms, present tense into past tense or vice versa.

b) Ordering Activities: The poem was presented in an incomplete or defected form and the students were required to restore it to its original or most plausible form.

c) Completion Activities (Cloze): certain elements from a poem were removed and the students were required to complete it with one appropriate word or phrase.

d) Comparison and Contrast Activities: The students were given two poems having the same or related themes. Then they were asked to note points of similarities and differences between the two poems.

e) Choosing the Best Paraphrase: The students were asked to choose between the two paraphrases of a poem and to express their reasons for their choice.

f) Expansion Activities: In this activity, the students were asked to add one or more lines to a poem, or to render a poem into a short story or a short play.

g) Reading the Poem Aloud: Reading aloud is one of the classroom techniques having its cons and pros among the language- teaching experts. Certain texts such as drama and poetry can come to life and can be more easily appreciated when read aloud.

6. Follow up Activities: Poetry writing is often ignored as a creative tool for learning many aspects of a foreign language. It is believed that poetry writing can serve as a way of enhancing the learner's feel for the language. In this part the students were asked to produce a short poem, either individually or more often in groups.

7. On Your Own: A few poems were given to the students to be read alone at home without following any kind of activities.

\section{Instrumentation}

For this study the following instruments were used:

1. The TOEFL was administered to the control and the experimental groups to make them homogeneous.

2. The Likert Attitude Scale was given to both control and experimental groups twice, before and after the treatment, to measure the students' attitude towards poetry.

3. A second questionnaire containing 25 items was distributed to both groups at the end of the experiment to assess their attitude toward English poetry as a complement to the Likert Attitude Scale.

4. Two Final tests were used in this study. One consisting of 20 items based on the materials given to the students to be read alone. The second final test consisting of 50 items was based on the material covered during the treatment sessions.

\section{DATA ANALYSIS}

As a longitudinal study, it took about 11 weeks to conduct the research experiment. Data consisting of attitude surveys, poetry and language proficiency tests was gathered from control and experimental groups before and after the treatment. To ensure the homogeneity of the groups in terms of their language proficiency the TOEFL was administered to all the groups in this study. A t-test was run to determine whether the difference between the groups was significant 
or not. The result of the t-test indicated that there was no significant difference between the groups as far as language proficiency was concerned before the experiment began. The Likert Attitude Scale was distributed to all the students in both the control and the experimental groups twice, once prior to and once after the experiment. Table 1 shows that there was no significant difference between the attitudes of the students toward the English poetry before the experiment began.

TABLE 1:

STUDENT's ATTITUDE TOWARDS POETRY BEFORE THE EXPERIMENT

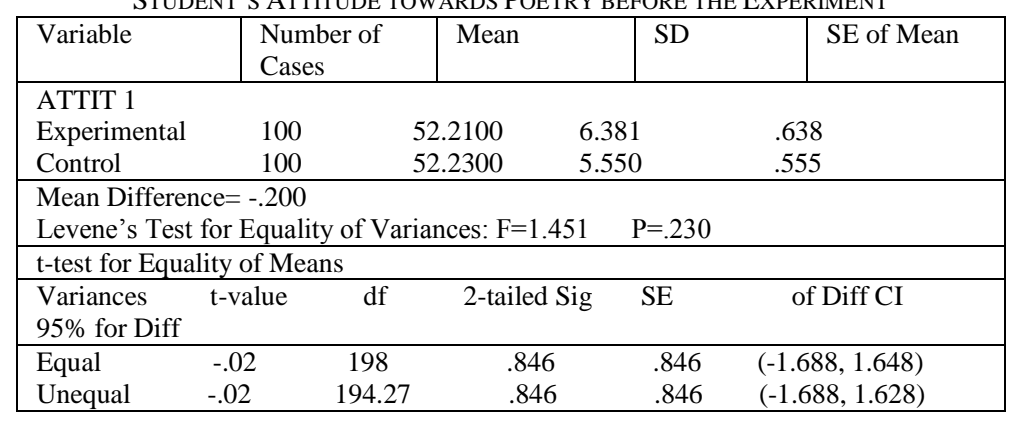

After the treatment the Attitude Scale was distributed again to find out whether there had been any changes in the students' attitude towards English poetry. The two groups were compared on their scores on the Attitude Scale using the t-test procedure. The .05 level of significance was employed. Table 2 shows the result of the analysis which indicates that there was significant difference between the groups on their change of attitude toward poetry.

TABLE 2:

STUdENTS' ATtITUde TOWARDS POETRY AFTER THE TREATMENT

\begin{tabular}{|c|c|c|c|c|c|}
\hline Variable & & $\begin{array}{l}\text { Number of } \\
\text { Cases }\end{array}$ & Mean & SD & SE of Mean \\
\hline \multicolumn{6}{|l|}{ ATTIT 1} \\
\hline \multicolumn{2}{|l|}{ Experimental } & 100 & 52.210 & 6.381 & .638 \\
\hline \multicolumn{2}{|l|}{ Control } & 100 & 52.230 & 5.550 & .555 \\
\hline \multicolumn{6}{|c|}{ Mean Difference $=-.200$} \\
\hline \multicolumn{4}{|c|}{ Levene's Test for Equality of Variances: $F=1.451$} & $\mathrm{P}=.230$ & \\
\hline \multicolumn{6}{|c|}{ t-test for Equality of Means } \\
\hline $\begin{array}{l}\text { Variances } \\
95 \% \text { for Diff }\end{array}$ & t-value & $\mathrm{df}$ & tailed Sig & SE & of Diff CI \\
\hline Equal & -.02 & 198 & .846 & .962 & $(-1.688,1.648)$ \\
\hline Unequal & -.02 & 194.27 & .846 & .962 & $(-1.688,1.628)$ \\
\hline
\end{tabular}

Besides the Likert Attitude Scale, a 25-item questionnaire was constructed and administered at the end of the treatment. The result obtained from the questionnaire as shown in Table 3 indicated that the change in the experimental group was statistically significant.

TABLE 3:

RESULT OF THE QUESTIONNAIRE

\begin{tabular}{|c|c|c|c|c|c|}
\hline Variable & & $\begin{array}{l}\text { Number of } \\
\text { Cases }\end{array}$ & Mean & SD & SE of Mean \\
\hline \multicolumn{6}{|l|}{ ATTIT 1} \\
\hline Experimental & & 100 & 17.420 & 3.37 & .338 \\
\hline Control & & 100 & 14.400 & 3.99 & .339 \\
\hline \multicolumn{6}{|c|}{ Mean Difference $=$} \\
\hline \multicolumn{6}{|c|}{ Levene's Test for Equality of Variances: $F=3.354$} \\
\hline \multicolumn{6}{|c|}{ t-test for Equality of Means } \\
\hline \multicolumn{6}{|l|}{$95 \%$ for Diff } \\
\hline Equal & 5.78 & 198 & .000 & .523 & $(1.989,4.051)$ \\
\hline Unequal & 5.78 & 192.72 & .000 & .523 & $(1.989,4.051)$ \\
\hline
\end{tabular}

As mentioned earlier, at the end of each session the students were supplied with a few poems to be read at home for their own pleasure. Utmost care was taken to hide the idea of their being tested on these poems. The result of the test as depicted in table 4 showed a tremendous difference between the groups. The experimental groups performed much better simply because they were more involved in poetry than the control groups. 
TABLE 4:

RESUlT OF THE TEST ON "READING ALONE"

\begin{tabular}{|c|c|c|c|c|c|}
\hline Variable & & $\begin{array}{l}\text { Number of } \\
\text { Cases }\end{array}$ & Mean & SD & SE of Mean \\
\hline \multicolumn{6}{|l|}{ ATTIT 1} \\
\hline Experimental & & 100 & 8.600 & 4.932 & .493 \\
\hline Control & & 100 & 8.860 & 3.005 & .401 \\
\hline \multicolumn{6}{|c|}{ Mean Difference $=$} \\
\hline \multicolumn{6}{|c|}{ t-test for Equality of Means } \\
\hline $\begin{array}{l}\text { Variances } \\
95 \% \text { for Diff }\end{array}$ & t-valu & $\mathrm{df}$ & 2-tailed $\mathrm{s}$ & SE & \\
\hline Equal & 5.89 & 198 & .000 & .635 & 4.993) \\
\hline Unequal & 5.89 & 190 & .000 & .635 & 4.993) \\
\hline
\end{tabular}

As a result of having positive attitude towards English poetry, the students in the experimental groups were more motivated to study for their final exam and obtained better scores than the control groups. The result is shown in table 5 .

TABLE 5:

THE RESUlT OF THE FINAL TEST

\begin{tabular}{|c|c|c|c|c|c|}
\hline Variable & & $\begin{array}{l}\text { Number of } \\
\text { Cases }\end{array}$ & Mean & SD & SE of Mean \\
\hline \multicolumn{6}{|l|}{ ATTIT 1} \\
\hline Experimental & & 100 & 38.160 & 8.235 & .823 \\
\hline Control & & 100 & 34.710 & 7.216 & .722 \\
\hline \multicolumn{6}{|c|}{ Mean Difference $=3.4500$} \\
\hline \multicolumn{6}{|c|}{ t-test for Equality of Means } \\
\hline $\begin{array}{l}\text { Variances } \\
95 \% \text { for Diff }\end{array}$ & t-value & & iled Sig & SE & of Diff CI \\
\hline Equal & 3.15 & 198 & .002 & 1.095 & $(1.290,5.610)$ \\
\hline Unequal & 3.15 & 194.64 & .002 & 1.095 & $(1.290,5.610)$ \\
\hline
\end{tabular}

\section{DISCUSSION AND CONCLUSION}

The traditional approach to teaching English poetry emphasises the single meaning principle and encourages disassociation of the self during reading. In this approach, the teacher analyses the imagery, the figurative language, poetic devices with the precision of a laboratory technician. The control groups taught by the traditional method in this study were not encouraged to express their personal understanding of the poem and lack of involvement prevented them from going beyond the superficial level of meaning to a more adequate understanding. They considered the facts, events and people of the poems in isolation of their feelings. The overemphasis on the technical aspects along with negligence of the students' personal reaction to meaning prevents enjoyment and leads to dislike of poetry.

So long as the teacher considers himself as the conductor of the orchestra and the students as players, the literary appreciation would not occur. Unless the students are involved in the process of reading and writing poetry, the literary experience is not possible and to foster this, the teacher should forget this role of the conductor and be one of the players.

The new approach to teaching poetry was designed to offer students ample opportunity to react to the poems based on their own experiences, emotions and ideas. The method provided them with tremendous encouragement to express their personal understanding of a poem rather than wait for the teacher's ready-made explanation. The students were told that a poem might offer various interpretations and that their ideas were as valid as anyone else's and that there was no absolute correct response with regard to literary meaning. These facts along with the various activities exploited in the study caused them to be more involved with the poems and urged them to read and reread them to find new meanings and interpretations. In the control groups the students did not volunteer to express their impressions of the poems and always waited for the teacher's final remark to memorise for the final exam.

Much of the pleasure of poetry lies in the creative reading that is caused as a result of involvement with the text which the new approach seeks to establish. This involvement with the poem serves as stimulation for further study, and consequently a change of attitude towards poetry. The findings of this study show a pre to post improvement in the experimental groups. The following findings were not reached through empirical comparison of the groups, rather they were noticed by the researcher during the treatment.

1. The number of students in the experimental groups who absented themselves from the class during the study was fewer than that of the control group.

2. The number of the poems composed by the experimental groups was not at all comparable to the few poems written by the students in the control groups.

3. The atmosphere of the classes in control and experimental groups was very different. Whereas I had active, lively and responsive students in the experimental groups, the students in the control groups were non-participants. 
The findings of this study and my long experience in teaching poetry to college-level students force me to conclude that using the New Approach to teaching poetry to EFL students will put them on the right track to appreciate poetry.

\section{REFERENCES}

[1] Arthur, B. (1968). Reading Literature and Learning a Second Language. Language Learning, 18/4 and 4.

[2] Brumfit, C. J. And Carter, R. A. (1986). Literature and Language Teaching. Oxford: Oxford University Press.

[3] Duff, A. and Maley, A. (1989). The Inward Ear. Cambridge: Cambridge University Press.

[4] Hirvela, A. and Boyle, J. (1988). Literature courses and student attitudes. ELT Journal, 42/3.

[5] Lazar, G. (1993). Literature and Language Teaching. Cambridge: Cambridge University Press.

[6] Parkinson, B. and Thomas H. R. (2000). Teaching Literature in a Second Language. Edinburgh: Edinburgh University Press Ltd.

[7] Povey, J. F. (1967). Literature in TESOL Programs: The Language and the culture. TESOL Quarterly, $1 / 2$.

[8] Povey, J. F. (1979). The Teaching of Literature in Advanced ESL Classes in Celce Murcia, M. And McIntosh, L. (eds.).

[9] Spack, R. (1985). Literature, Reading, Writing and ESL: Bridging the Gaps. TESOL Quarterly, 19/4.

[10] Widdowson, H. G. (1975). Stylistics and the Teaching of Literature. London: Longman.

[11] Widdowson, H. G. (1984). Explorations in Applied Linguistics 2. Oxford: Oxford University Press.

Mohammad Khatib is Assistant Professor of TEFL at Allameh Tabataba'i University. He holds a Ph.D. in TEFL (Allameh Tabataba'i University, 1999), an M.A. and a B.A. in English Literature from Tehran University (1977 and 1972 respectively).

$\mathrm{He}$ began teaching at Allameh in 1981 and presently offers graduate and post-graduate courses in SLA Theories, Methodology, Literature in EFL Classes and English Literature.

His main areas of interest include SLA Theories, language learning strategies, culture and the integration of language and literature. He has published some articles on TEFL in Iranian Journals of Applied Linguistics. He has translated a book of short stories from famous writers of the world and published a guidebook on Shakespeare's selected sonnets. 